\title{
Study on the Realization Approach to Introduce Outstanding Traditional Culture to College Ideological and Political Education
}

\author{
Lihua Wang \\ Liaoning Economic Management Cadre Institute, Shenyang Liaoning 110122
}

Keywords: Outstanding Traditional Culture; College Ideological and Political Education; Education

\begin{abstract}
Outstanding traditional culture is the essence of Chinese nation, and college ideological and political education is the main channel to strengthen the education of national successors. In addition, the combination of traditional culture and college ideological and political education is developed as time requires. We have to start from the perspectives of traditional courses and also pay attention to campus culture atmosphere construction, talents cultivation mode based on cultural thoughts and further dig deep into the ideological and political education approaches.

By taking advantage of the fact that our country is vigorously promote outstanding traditional culture, we can dig deep into the connotation of traditional holidays, widely carry out excellent traditional cultural education activities, take the initiative to launch practical activities related to traditional culture so as to realize the introduction of outstanding traditional culture to college ideological and political education.
\end{abstract}

\section{Construct College Cultural Course System}

The culture study in colleges is the main way for college students to acquire scientific and cultural knowledge, which is also the most effective approach to inherit and carry forward the traditional culture. The construction of college culture curriculum system can promote the integrity of knowledge system, and is conducive to carry forward the traditional culture and contribute to the absorption and inheritance of traditional culture for students born after 1995.

The General Quality Education Courses Should be Related to Traditional Culture .The general quality education course is a pivotal course created to improve students' quality complying with the quality education reform. It takes improving students' comprehensive competence as the ultimate goal according to the requirement of government and is accepted by students born after 1995. In recent decades, many domestic colleges have attached great importance to the overall quality of students and take general quality education as the main course among interdisciplinary courses. Generally speaking, general quality education courses include the following four types: first, common sense of Chinese culture; second, global view guide; third, science and economy society; fourth, basic humanities and the classics reading. This kind of course setting is able to systematically improve students' common sense and broaden their horizon in terms of humanity qualities; the traditional culture will inevitably make a difference and they can select the essence and discard the gross. Before the college entrance exam, students study because they want to pass the exam and after entering into college, they will be granted excess to strengthen humanity cultivation and understand better of cultural connotation. Hence, they will become talents and they will feel proud deep inside.

College Ideological and Political Courses Should be Related to Traditional Culture. College ideological and political course is an important course highlighted by the Department of Education, which is also a basic and required course in college, the theoretical result of Sinicism of Marxism, and core ideological and political teaching content with Chinese socialism characteristics. After implementing the college entrance exam system, we kept exploring proper ideological and political teaching contents and methods while college ideological and political course is a perfect match adapted to the requirement of the new time. However, we cannot forget the traditional culture of China and benevolence, justice, courtesy, wisdom, faith should also be continued. Concerning the fact that students born after 1995 are faced with the reform period and are affected by the western culture, they barely have any knowledge of Chinese traditional culture. Therefore, college 
ideological and political courses should explore outstanding traditional culture and introduce to normal teaching contents. Take Ideological \& Moral Cultivation and Fundamentals of Law as an example, the course setting, teaching contents and teaching methods should be organically combined. In chapter two, we can introduce loyalty while introducing inheriting the spirit of patriotic tradition of China and closely relate the innovative spirit behind patriotism; in chapter four of paying attention to moral tradition and moral practice, we should highlight revolutionary morality along with video materials to let students realize how great the revolutionaries are so as to leave a deep impression on them; in chapter five of obeying moral rules and polishing characteristics, we should pay attention to online morality to carry out honest education in practice; in chapter seven of establishing an awareness of law and respecting the authority of law, we should combine the law culture to spread the juridical logic and connotation. In this way, we can make traditional culture classes more vivid and colorful.

College Core Courses Should Embrace Traditional Culture. Besides Ideological and Political Humanity Education Cultivation, Students Pay more Attention to Professional Courses. The best way to make it not boring for students and embrace traditional culture to daily activities is to introduce traditional culture in professional course teaching. From the perspective of most teachers, professional courses are professional courses which are completely not related to traditional culture education. However, lots of facts have told us that, the classes combining traditional culture are more popular among students. A legend of Zhejiang University called Su Dekuang is the most popular math teacher among students and he has been teaching for 28 years. $\mathrm{He}$ is close to his $60 \mathrm{~s}$ but is able to make boring math to philosophy. In order to attend his class, lots of students will go to the classroom earlier so as to have a seat. He often combines math with daily stuff to make it more interesting. For example, he one questioned his students: why will people run into the tree while driving the car? One cause might be the car is running toward the direction of the tree and the other cause might be the speed is too quick. Therefore, the change rate of function value from point $\mathrm{P}$ to director $\mathrm{L}$ is the same rule of a car running into a tree, one is about direction and one is about speed. Another popular saying is, he is your strict increasing function, so your life will be happier and happier. I hope your love is like a ray with only a starting point and no ending. These kind of professional math classes will never make students feel bored.

\section{Create Outstanding Traditional Culture and Campus Atmosphere}

The cultural campus atmosphere is deemed as an intangible force, which will imperceptibly improve students' cultural competence. Nowadays, colleges in China do not pay much attention to creating a cultural atmosphere but actually Chinese culture should be introduced to campus construction.

United front Culture Promotion. United front work is considered as an ever-lasting factor for culture, and it is beneficial for united front culture promotion. No matter party members or no party-members should adhere to One China Policy based on socialism with Chinese characteristics, the unity of patriotism and socialism and economic globalization. In addition, we should carry forward the tradition of loyalty and patriotism, closely combine the contemporary mission of college students with socialism construction. help them establish lofty ideals and aspiration so as to achieve the great goal of Chinese dream. The formation of cultural atmosphere cannot be completed by one step, which should be cultivated as a every-lasting value from the perspective of college students. The time in college is the important stage for the formation of people's correct values and only by helping them cultivating a rational value can they help to the sustainable development for the future.

Cultural Promotion of Campus Network Media. Along with the wider coverage of network media, we can conclude that the modern technology cannot only improve the scientific work of cultural work in college but also help with the cultural promotion so as to realize the unlimited communication between information and thought and demonstrate the characteristics of this era. Concerning the cultural formation of network media, we have to adopt a dimensional model which can judge from a comprehensive view. For example, the restaurant should be equipped with 
television and audio so as to give students the access of the big events both at home and abroad, the reform progress in time, and they can also appreciate various popular music especially popular web songs. Concerning the accommodation, we should introduce security and safety. The period before orientation and graduation ceremony there will be strangers and steal stuff such as computers etc. In this occasion, monitoring facilities are essential but the most important point is that we have to cultivate students' awareness of self-protection. Finally, the public opinion of campus: we should carry out self-regulation committee by students themselves. For example, quality education lecturers, health knowledge lecturers, midday news should be hold frequently in order to help students hear the voice of culture. Also, they should understand online celebrities and superstars in a correct way. Diverse cultural promotion will inevitably bring students with a good knowledge of culture.

Art Performance in School Art Festival. School art festival is a large-scale cultural show created based on the ideas of college students, which is also a good opportunity for students to entertain and demonstrate themselves. Nowadays, the students born after 1995 should not only seek fashion but also pay attention to traditional culture. While plan art festivals, we should introduce Chinese culture. For example, we can introduce Chinese zither and pipa (a plucked string instrument with a fretted fingerboard) so as to let students enjoy the beauty of much. Moreover, we can also introduce ethnic dances to bring students together to applaud the charm. Furthermore, the Long March can be made to dramas to help students know the revolutionary feelings. No mater songs, dances or instrument performance can drive people's passion for culture and put Chinese people together.

Introduce good tradition to students' daily management. Chinese culture pays attention to teaching with skills and patience while modern students pursue quick speed and high quality, which is against traditional rules. In order to cultivate students' life-long competence, we can adopt gradual assessment. We should divide students' activities into different types: behaviors, academy, cultural and ethnical quality as well as social competence. To begin with, behavior is mainly to cultivate students' behaving right. Students should conduct civilized communication, be quiet in public, obey school rules, treat people nicely, adhere to the curfew etc. Second, the academic cultivation is mainly to make people learn in a good academic environment. They should go to class, listen to teachers and finish their assignment, seriously treat exams and avoid cheating as required. In addition, they should also take the initiative to participate in various competence activities to her create a good academic environment. Third, cultural and ethnical quality is to comprehensively improve students' qualities, including the ability to endure, to compete and to construct a team. Finally, social competence is to cultivate students' ability to be adapted to the society and deal with stuff by themselves. Social cognition, interpersonal communication, study exchange and enterprise culture obedience are deemed as important qualities for students to be adapted to the society. Only by continually studying, can we be embraced quickly.

\section{Establish Identify of Excellent Traditional Culture in the Society}

The promotion of outstanding traditional culture is not the responsibility of schools but the mission of all the society. Actually every Chinese people have their own responsibility from the perspective of making the Chinese tradition last. So, all the society should reach a sense of identify to feel the glory of our culture.

Try to Introduce Outstanding Traditional Culture to Social Practice for College Students. To apply knowledge into reality, college students have to participate in social practice. President Mao once said, practice is the sole criterion for testing truth. By visiting exhibitions, reading the words written there can help students create an identity and a sense of belongs. To participate in social practice, such as distributing leaflets, acting as a waiter etc. will enable students to be exposed to different cultures and realize the pivotal role communication played in making it work. What's more, exploring the activities of popularizing the traditional culture education will also make students feel the charm of it and realize the importance to cultivate they own qualities. The social practice activities in summer and winter holiday can enhance students to share their 
experience and see their own growth. For example, while visiting a tourism spot, they awareness to protect the rational cultural heritage will be improved and will obey the rules to act as examples and get rid of uncivilized behaviors.

Combining Enterprise Culture and Traditional Culture in School-Enterprise Cooperation. When students go to the society, they might feel confused and they need school-enterprises cooperation to help them and guide the direction for them in advance. To introduce excellent enterprise culture to college ideological and political education can help students understand it and at the same time memorize the connotation of Chinese culture. Based on this, they are able to deeply understand enterprise culture so as to embrace it from multiple perspectives and be adapted to management as soon as possible. For example, the principle to recruit employees of Mengniu is that talents who are equipped with morality and abilities will be prioritized; those with morality but no ability can be cultivated; those with ability but no morality are avoided in someway; those without morality and ability cannot be accepted. NIU Gensheng, the CEO of Mengniu once elaborated this principle in a public show to employ people based on justice and fairness and he also focused on the continuity of enterprise culture. In reality, this rule adheres to the Chinese tradition to pay attention to both morality and talent. Emphasizing morality is a good tradition of China and cultivating talents is the ever-lasting goal. So, when you understand Chinese traditional culture well, you will definitely understand the recruit philosophy and be adapted to this culture quickly.

The Affect of Family Culture Atmosphere on Students. Family is an important role in every's growth and the family culture atmosphere will affect students' ideological and political education up to $30 \%$ among all the causes. For example, a family loves reading will cultivate a child's habit of reading. What's more, in reading, children will cultivate their interest. In a democratic family, children are allowed to discuss and to identify the Chinese culture. Different families have different teaching styles, which will inevitably bring different effects on children. So the key we have to know is to cultivate their trust and encourage them to participate in all kinds of activities.

All in all, outstanding traditional culture has diverse contents and is shown in different ways. It will be very helpful if we introduce the good essence of tradition to college ideological and political education. Nowadays, we will definitely cultivate soaring excellent talents.

\section{Fund Project}

Shenyang City Social Science Association Issue in 2017 "Chinese traditional culture to lead the ideological and political education of college students" (Project Leader: Wang Lihua, Project No.: SYSK2017-23-19)

\section{References}

[1] Li Yuqian. Study on the infiltration of outstanding cultural education in college ideological and political education [J].Journal of Jinan Vocational College, 2013 (2)

[2] Yang Hanmin. Close relation of ideological and political education to traditional culture [J]. Journal of CPCC Shanxi Provincial Committee Party School, 2013(4).

[3] Li Yang, Liang Ting. Study on the introduction of excellent traditional culture to college ideological and political education [J]. New West, 2014(3): 2.

[4] Zou Lixia. The combination of Chinese outstanding traditional culture and ideological and political education [J]. Weekly test, 2014(4)

[5] Zhang Lin. Overview of traditional culture and ideological and political education [J].Journal of Chongqing Radio Television University, 2013 (3)

[6] Shi Haiying. Enlightenment of Chinese traditional culture to modern ideological and political education [J]. Ideological and Theoretical Studies, 2013 (16)

[7] $\mathrm{Wu}$ Dongsheng etc. History of ideological and political education in China[M]. Nankai University Press, 2013

[8] Zhong Yongsheng. Inheritance and rehabilitation: Interpretation of Chinese culture with core 
socialist values [M].China Youth Press, 2015.01.

[9] Chen Ting. Study on college ideological and political education paths from the perspective of rational culture $[\mathrm{J}]$. Western Quality Education, 2015, 11:34

[10]Chen Ting, An Jianping. Approaches to play the orientation function of ideological and political education in micro era[J]. People's Forum, 2016 (02): 183-185. 